\title{
Octasilsesquioxane Chemistry II. Hydrosilylation Reaction of Octa(hydrido)silsesquioxane with Unsaturated Substrates and Product Properties
}

\author{
Ling-Kang Liu ${ }^{\mathrm{a}, \mathrm{b} *}$ ( 劉陵崗) and Enock O. Dare ${ }^{\mathrm{a}, \mathrm{c}}$ \\ a Institute of Chemistry, Academia Sinica, Nankang, Taipei, Taiwan 11529, R.O.C. \\ ${ }^{\mathrm{b}}$ Department of Chemistry, National Taiwan University, Taipei, Taiwan 10767, R.O.C. \\ ${ }^{\mathrm{c}}$ Department of Chemical Science, University of Agriculture, Abeokuta, Nigeria
}

\begin{abstract}
The hydrosilylation reaction of octa(hydrido)silsesquioxane with $\omega$-halo-1-alkenes and other unsaturated substrates allows attachment of 8 long-chain functionalized alkyls on the cubic $\mathrm{Si}_{8} \mathrm{O}_{12}$ skeleton. $\mathrm{Pt} / \mathrm{C}$ and $\mathrm{H}_{2} \mathrm{PtCl}_{6}$ have been adopted as the catalysts, the yields being 74-98\% for compounds 2-9. For terminal alkenes, the hydrosilylation follows the anti-Markonikov's rule. The morphological state of 2-9 ranges from viscous liquid to crystalline materials. The pyrolysis results indicate that 7 , a material of hard spherical core and soft flexible shell, may likely act as nanometer-size ball bearings up to more than $400{ }^{\circ} \mathrm{C}$. The X-ray structure of 9 reveals that the molecule is required to possess a center of symmetry crystallographically. The linear arms on 9, except for two of them, are virtually all-trans in conformation, not counting the $\omega$-C-Cl bond.
\end{abstract}

Keywords: Octasilsesquioxane; Hydrosilylation; Nanocomposites; Pyrolysis.

\section{INTRODUCTION}

Because of the length scales involved, nanocomposite materials incorporate extensive interfacial interactions that can result in non-linear changes in the composite property. ${ }^{1}$ Such changes in the nano region are so great that the rules commonly used to estimate the macroscopic property of composites no longer hold. The nanocomposites then offer potential access to completely new classes of materials with unique properties. One of the more difficult problems with nanocomposites is in developing synthetic and processing approaches that precisely define the volume and shape of individual phases and their periodicity.

Chemists often start from a much reduced domain-size and work at the molecular level, incorporating polymerizable inorganic and organic constituents in the molecule to build organic/inorganic hybrids that combine advantageous properties of disparate components. ${ }^{2}$ Silsesquioxanes $\left(\mathrm{RSiO}_{1.5}\right)_{\mathrm{n}}$, derived from, e.g., $\mathrm{RSiCl}_{3}$ or $\mathrm{RSi}(\mathrm{OEt})_{3}$ by hydrolysis/condensation in a sol-gel process, are a class of silicate frameworks where each $\mathrm{Si}$-atom is linked covalently to an organic radical $\mathrm{R} .^{3}$ Because of the introduction of $\mathrm{R}$, these polymeric/oligomeric species are chemically modified silicates. Physically for instance, they have completely different thermal behaviors from silicates without modification. Structurally, silsesquioxanes consist of tetrahedral silicon atoms, each being a ' $\mathrm{T}$ ' unit, ${ }^{4}$ i.e., connected to three $\mathrm{O}$-atoms and one $\mathrm{R}$ group. The $\mathrm{O}$-atoms are bridges between $\mathrm{Si}$-atoms belonging to different $\mathrm{T}$ units, or between $\mathrm{Si}$ - and $\mathrm{H}$-atoms. Among many other incompletely condensed silsesquioxanes is also the octa(hydrido)silsesquioxane, $\mathrm{H}_{8}-\mathrm{T}_{8}$, which is completely condensed with a cubane-shaped structure, is suitable for more structural elaboration. ${ }^{5}$ The intention of this work is to produce hybrid nanomolecules from $\mathrm{H}_{8}-\mathrm{T}_{8}$ via addition of organic moieties, the target being a $\mathrm{Si}_{8} \mathrm{O}_{12}$ core carrying 8 functionalities for later use in starburst dendrimers. ${ }^{6}$
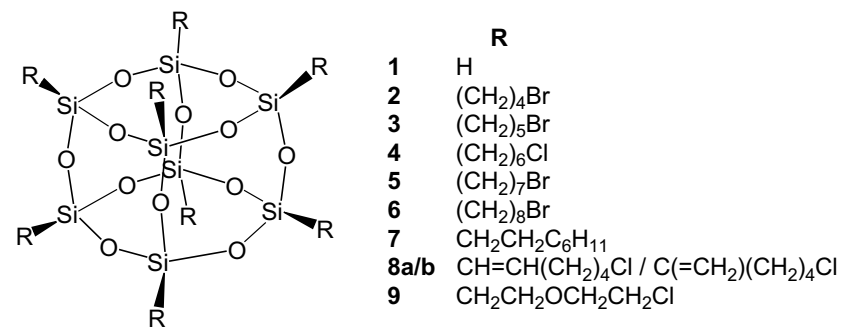

\section{RESULTS AND DISCUSSION}

\section{Attempted synthesis of $\mathrm{H}_{8}$ - $\mathrm{T}_{8}$ with solid acid route}

$\mathrm{H}_{8}-\mathrm{T}_{8}$ was first synthesized serendipitously in 1958 at $<1 \%$ yield from $\mathrm{HSiCl}_{3}$. ${ }^{7}$ There have been a number of improved preparations since. Agaskar reported a much more reproducible procedure in 1987 and described a purification protocol to yield gram quantities of $\mathrm{H}_{8}-\mathrm{T}_{8}, \mathrm{H}_{10}-\mathrm{T}_{10}, \mathrm{H}_{12}-\mathrm{T}_{12}$, 
and $\mathrm{H}_{14}-\mathrm{T}_{14} .{ }^{8}$ Our current preparation follows the method reported by Agaskar in 1991, ${ }^{9}$ the yield of $\mathrm{H}_{8}-\mathrm{T}_{8}$ being $17.5 \%$ based on $\mathrm{HSiCl}_{3}$. As large amounts of Bronsted acid $\mathrm{HCl}(\mathrm{aq})$ and Lewis acid $\mathrm{FeCl}_{3}(\mathrm{aq})$ were used in the Agaskar preparation, we thought about the possibility of using a solid acid as a replacement for $\mathrm{HCl}(\mathrm{aq})$ and $\mathrm{FeCl}_{3}(\mathrm{aq})$, and facilitating the purification steps after condensation. Thus the mixed $\mathrm{CH}_{3} \mathrm{OH} /$ hexane in a round-bottomed flask over acid Amberlite (IR 120) was introduced with hexane-diluted $\mathrm{HSiCl}_{3}$ from a dropping funnel over a long period of time, keeping the mixture under constant stirring. Then the standard Agaskar purification protocol yielded exclusively $\mathrm{H}_{8}-\mathrm{T}_{8}$, however in just $5.1 \%$ yield (Scheme I). According to our own experiences, the utility of solid acid Amberlite has improved many other preparatory methods. ${ }^{10}$ But the low yield of $\mathrm{H}_{8}-\mathrm{T}_{8}$ in this attempt was below expectations. A large percentage of insoluble resinous material was isolated whose ${ }^{1} \mathrm{H}$ NMR spectrum clearly exhibited no proton resonance at all, suggesting the $\mathrm{H}$ loss during the sol-gel process of $\mathrm{HSiCl}_{3}$ with addition of acid Amberlite.

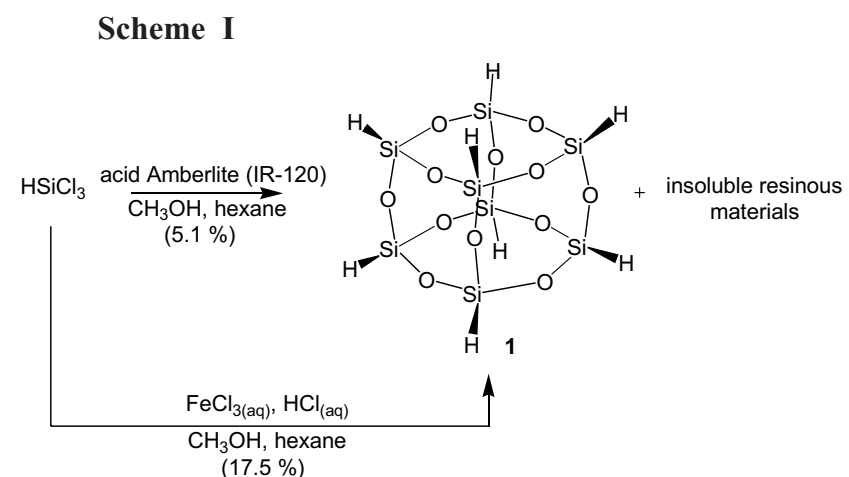

\section{Hydrosilylation on $\mathrm{H}_{8}-\mathrm{T}_{8}$ with alkenes}

Among the principal objectives of this work is one directed towards the synthesis of novel, stable, polyhedral silsesquioxanes carrying various $\mathrm{Si}-\mathrm{R}$ substituents. The direct condensation of $\mathrm{RSiCl}_{3}$ to form $\mathrm{R}_{8}-\mathrm{T}_{8}$ in a sol-gel process ${ }^{11}$ involves both a monomer $\mathrm{RSiCl}_{3}$ synthesis and a solgel procedure. For each different sol-gel preparation, there are different issues of side reactions and tedious optimizations. And hence modification on an existing $\mathrm{Si}_{8} \mathrm{O}_{12}$ skeleton without breaking apart the core is more commonly adopted. In the literature, vinyl $\mathrm{l}_{8}-\mathrm{T}_{8},{ }^{12} \mathrm{Ph}_{8}-\mathrm{T}_{8},{ }^{13}$ and $\mathrm{H}_{8}-\mathrm{T}_{8}$ all have been synthesized to serve as an intermediate and subject to modification to yield $\mathrm{R}_{8}-\mathrm{T}_{8}$.

In order to functionalize organic/inorganic nanocomposites, currently one of our attempts is to attach long-chain $\omega$-halogenated functionality to all of the Si-atoms on cubic silsesquioxanes, and we have carried out experiments on $\mathrm{H}_{8}-\mathrm{T}_{8}$ employing the hydrosilylation reaction, which is an important reaction in Si chemistry, converting $\mathrm{Si}-\mathrm{H}$ bond to $\mathrm{Si}-\mathrm{C}$ bond by 1,2 -addition of the $\mathrm{Si}-\mathrm{H}$ moiety onto an unsaturated $\mathrm{C}-\mathrm{C}$ bond. ${ }^{14} \mathrm{In}$ this manuscript, we report the reaction of $\mathrm{H}_{8}-\mathrm{T}_{8}$ and a series of $\omega$-halogenated terminal alkenes to produce new octa( $\omega$-halo-alkyl)silsesquioxanes. The hydrosilylation reaction has been found to proceed with retention of the $\mathrm{Si}_{8} \mathrm{O}_{12}$ skeleton. $\mathrm{Pt} / \mathrm{C}$ and $\mathrm{H}_{2} \mathrm{PtCl}_{6}$ have been adopted as the catalysts ${ }^{15}$ with various $\omega$-halo-1-alkenes as the unsaturated substrates (Scheme II): 4-bromo-1-butene, 5-bromo-1pentene, 6-chloro-1-hexene, 7-bromo-1-heptene, and 8bromo-1-octene; together with other unsaturated substrates: vinylcyclohexane, 6-chloro-1-hexyne, and 2-chloro-ethylvinylether. The reactions of the last three substrates are shown as examples in Scheme III. The hydrosilylation was carried out with excess unsaturated substrates at reflux. The yields were excellent following the anti-Markonikov's rule for alkenes and the purification very simple. The reaction was monitored by ${ }^{1} \mathrm{H}$ NMR spectroscopy, noting the disappearance of resonance at $\delta 4.19$, and the emergence of appropriate peaks due to expected products. The products 2-9 were analyzed spectroscopically with good elemental analysis data. The morphological state of 2-9 ranges from viscous liquid to crystalline materials (Table 1). The viscous nature of liquids with increasing carbon length attached to the $\mathrm{Si}_{8} \mathrm{O}_{12}$ framework was particularly observed.

\section{Scheme II}

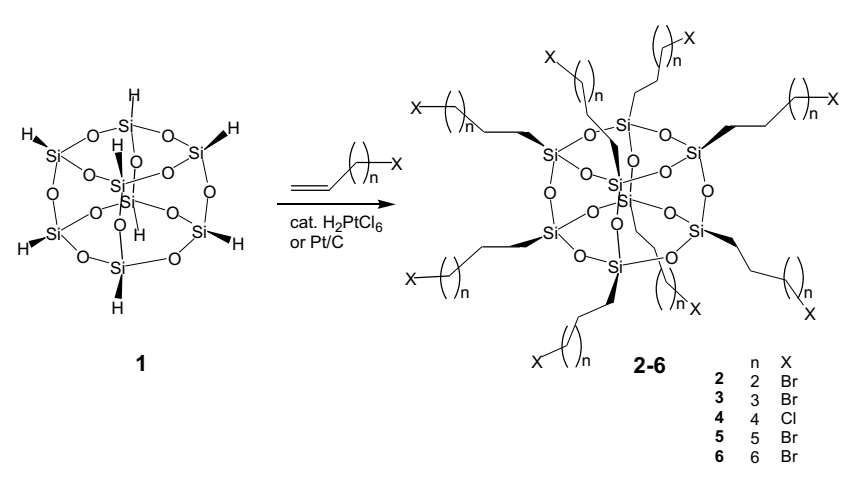

The comparison between $\mathrm{Pt} / \mathrm{C}$ and $\mathrm{H}_{2} \mathrm{PtCl}_{6}$ as the hydrosilylation catalysts is as follows. It was found that the latter, homogeneous in nature, effectively hydrosilylated all the unsaturated substrates listed earlier, whereas the former was selective towards that of $\omega$-halo-1-alkenes. There was no reaction when $\mathrm{Pt} / \mathrm{C}$ was adopted as catalyst in the cases of vinylcyclohexane, 6-chloro-1-hexyne, and 2-chloroethyl- 


\section{Scheme III}

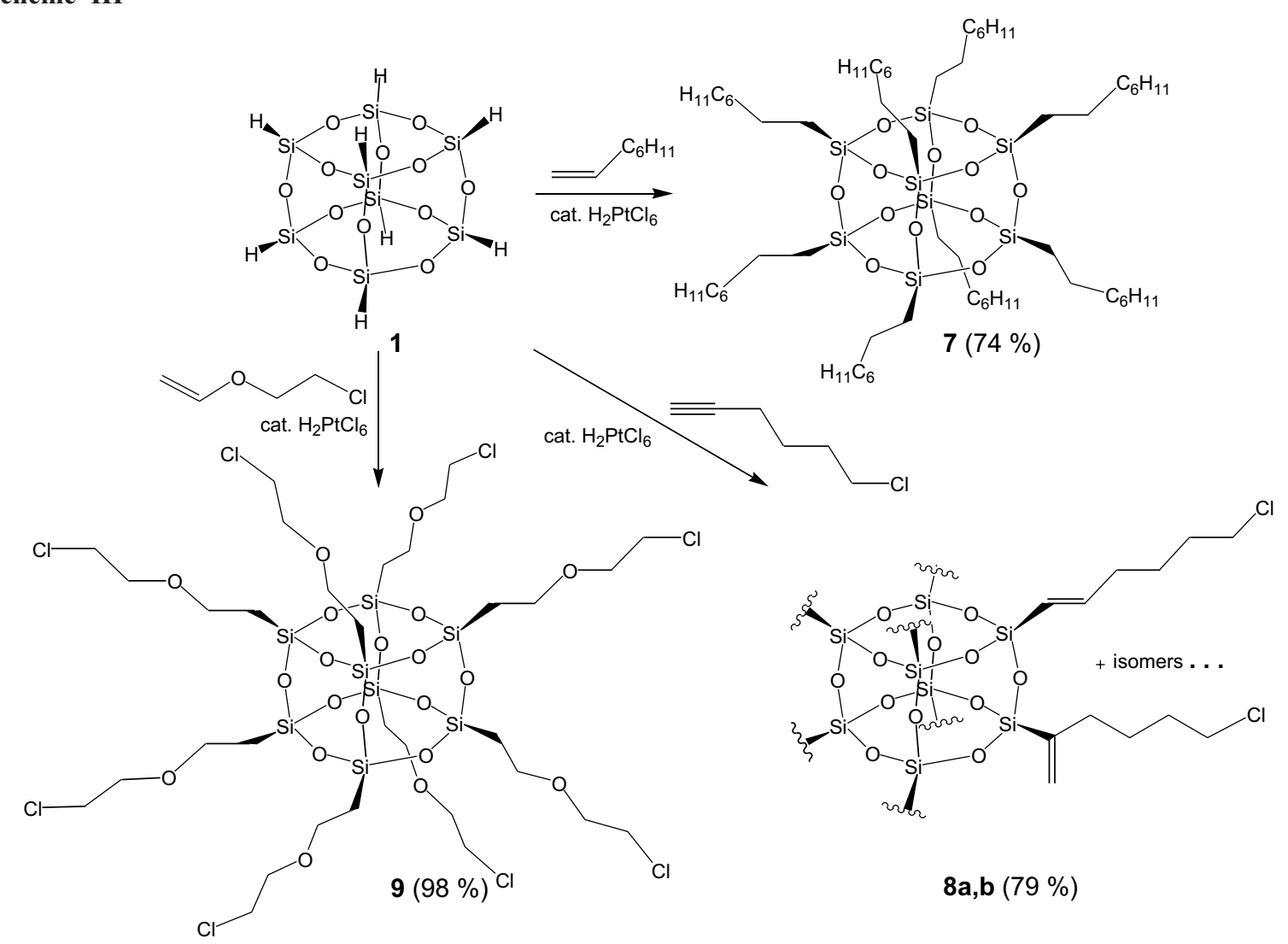

vinylether to produce 7-9 (see Table 1, entries 6-8). Compared to $\mathrm{Pt} / \mathrm{C}, \mathrm{H}_{2} \mathrm{PtCl}_{6}$ has been judged to be more applicable overall, and its effectiveness at very low concentration has been quite remarkable. The production of 2-9 involves 8 steps of hydrosilylation reactions on a single $\mathrm{Si}_{8} \mathrm{O}_{12}$ skeleton; the yields ranging $74 \%$ - 98\% suggest almost complete conversion for each step. The generally accepted reaction mechanism based on fundamental transition metal reactions in-

Table 1. Preparation and Properties of $\mathrm{R}_{8}-\mathrm{T}_{8}$

\begin{tabular}{|c|c|c|c|c|c|}
\hline Entry & Product & Catalyst, Solvent & Yield & Physical state $^{\mathrm{a}}$ & $\mathrm{M}^{+}$ \\
\hline \multirow[t]{2}{*}{1} & 2 & $\mathrm{H}_{2} \mathrm{PtCl}_{6}$, neat & 88 & Brown liquid & 1504.0 \\
\hline & & $\mathrm{Pt} / \mathrm{C}$, neat & 90 & & \\
\hline \multirow[t]{2}{*}{2} & 3 & $\mathrm{H}_{2} \mathrm{PtCl}_{6}$, neat & 98 & White solids & 1617.3 \\
\hline & & $\mathrm{Pt} / \mathrm{C}$, neat & 99 & & \\
\hline \multirow[t]{2}{*}{5} & 4 & $\mathrm{H}_{2} \mathrm{PtCl}_{6}$, neat & 98 & Colorless liquid & 1373.2 \\
\hline & & $\mathrm{Pt} / \mathrm{C}$, neat & 86 & & \\
\hline \multirow[t]{2}{*}{4} & 5 & $\mathrm{H}_{2} \mathrm{PtCl}_{6}$, toluene & 90 & Brown liquid & 1841.4 \\
\hline & & $\mathrm{Pt} / \mathrm{C}$, toluene & 74 & & \\
\hline \multirow[t]{2}{*}{5} & 6 & $\mathrm{H}_{2} \mathrm{PtCl}_{6}$, neat & 96 & Brown liquid & 1952.2 \\
\hline & & $\mathrm{Pt} / \mathrm{C}$, neat & 88 & & \\
\hline \multirow[t]{2}{*}{6} & 7 & $\mathrm{H}_{2} \mathrm{PtCl}_{6}$, hexane & 74 & White micro crystals & 1306.7 \\
\hline & & $\mathrm{Pt} / \mathrm{C}$, hexane & $\mathrm{l}$ & & \\
\hline \multirow[t]{2}{*}{7} & $8 a, b$ & $\mathrm{H}_{2} \mathrm{PtCl}_{6}$, toluene & 79 & Light brown liquid & 1357.1 \\
\hline & & $\mathrm{Pt} / \mathrm{C}$, toluene & $\mathrm{b}$ & & \\
\hline \multirow[t]{2}{*}{8} & 9 & $\mathrm{H}_{2} \mathrm{PtCl}_{6}$, neat & 98 & Colorless crystals & 1275.1 \\
\hline & & $\mathrm{Pt} / \mathrm{C}$, neat & & & \\
\hline
\end{tabular}

${ }^{\mathrm{a}}$ At room temperature. All liquids are highly viscous. ${ }^{\mathrm{b}}$ No reaction. 
cludes oxidative addition of $\mathrm{Si}-\mathrm{H}$ bond on $\mathrm{Pt}$, olefin coordination, migratory 1,2-insertion of hydride, and reductive elimination, that is, the 'Chalk-Harod' mechanism ${ }^{16}$ as further extended by Speier. ${ }^{17}$ The regioselectivity favoring linear products in the cases of $\omega$-halo-1-alkenes as substrates is attributable to steric bulkiness of the $\mathrm{Si}_{8} \mathrm{O}_{12}$ core.

Compounds 2-9, prepared under nitrogen atmosphere, are stable under air. The ${ }^{1} \mathrm{H}$ NMR taken before and after exposing them to air for $2 \mathrm{~h}$ gave no differential observation. Overall the Pt-catalyzed hydrosilylation reaction of $\mathrm{H}_{8}-\mathrm{T}_{8}$ provides convenient access to $\omega$-halo-functionalized cubic silsesquioxanes.

In the case of vinylcyclohexane (Table 1 , entry 6 ), the steric energy of cyclohexane groups caused a relatively lower yield of 7. In the case of 6-chloro-1-hexyne (Table 1, entry 7), the products $\mathbf{8 a}, \mathbf{b}$ were found to be a mixture of isomers, attributed to $\alpha$ - and $\beta$-additions. Gentle and Bassindale reported that $\beta$-addition and side reactions can be suppressed if the steric bulkiness on the $\gamma$-position of the unsaturated substrates increases. ${ }^{18}$ In the case of 2-chloroethylvinylether (Table 1 , entry 8$)$, the ether functionality might also have caused a slight decrease on the yield of 9 ( $c f$. yields of $\mathbf{3}, \mathbf{4})$.

\section{Pyrolysis of compounds 3,7 , and 9}

Polysiloxanes, and a few of the octa(alkyl)silsesquioxanes have already received attention as precursors to ceramics and special glasses, for example, to silicon carbide, silicon oxycarbide and silicon oxynitride glasses. Out of the new $\mathrm{R}_{8}-\mathrm{T}_{8}$ compounds, only $\mathbf{3}, \mathbf{7}$, and $\mathbf{9}$ are solid samples whose thermolysis under normal conditions has been carried out in order to evaluate their relative thermal stability and possible ceramics-making potential. Fig. 1 shows the results of a thermogravimetric analysis study.

The three selected compounds are reasonably stable. All of them remain at constant weight below $350{ }^{\circ} \mathrm{C}$, with the temperature of $10 \%$ weight loss occurring at 381,442 , and $338^{\circ} \mathrm{C}$, for $\mathbf{3}, \mathbf{7}$, and $\mathbf{9}$, respectively, compound 7 being the most stable. Both 3 and 7 have single step weight loss whereas 9 shows more than one step as reasonably expected from its ether linkages. The bromosilsesquioxane $\mathbf{3}$ is also seen thermally more stable than the chlorosilsesquioxane 9. The high thermal stability of $\mathbf{7}$ is attributed to its branching arms that carry one cyclohexyl group as the end group each (many more cyclic atoms on 7 relative to that on $\mathbf{3}$ and $\mathbf{9}$ ). Compound 7 is likely a much better material consisting of hard spherical cores and soft flexible shells that may act as nanometer-size ball bearings at above $400{ }^{\circ} \mathrm{C}$. It has been conceived that at high temperatures, mineralization takes place. This degradation process involves the cleavage of many organic (and inorganic) bonds, leading to the escape of pyrolyzed small molecules before the formation of inorganic black glasses. The total weight loss of 7 and 9 exceeds $80 \%$ and is thus greater than the organic fraction of the materials, indicative of decomposition and rearrangement under the formation of larger siloxane structures and/or silicon oxycarbide. $^{19}$

\section{X-ray crystal structure of 9}

Compounds 3, 7, and 9 exist as solid microcrystals, out of which crystals suitable for X-ray diffraction studies were grown successfully for $\mathbf{9}$, from ether and from hexane/acetone. Single crystal X-ray structure analysis revealed clearly the molecular connectivity of 9 , as shown in Fig. 2. The molecule is required crystallographically to possess a center of symmetry. The linear arms, except that extending from $\mathrm{Si}$, are virtually all-trans in conformation till $\omega-\mathrm{C}-\mathrm{Cl}$. The arm extending from $\mathrm{Si} 2$ exhibits a disorder in the terminal region, the disorder being common in the X-ray structure study of silsesquioxanes. The structural parameters of the core $\mathrm{Si}_{8} \mathrm{O}_{12}$ are normal, similar to those found in the structures deposited in the Cambridge Structural Databases. On average of 9 published structures ${ }^{20}$ with an R-factor less than 0.10 , the core $\mathrm{Si}-\mathrm{O}$ bond length is $1.616 \pm 0.007 \AA$, and the core $\angle \mathrm{O}-\mathrm{Si}-\mathrm{O}$ bond angle is $149.0 \pm 4.3^{\circ}$.

\section{EXPERIMENTAL SECTION}

\section{General}

All manipulations were performed under an atmosphere of pre-purified nitrogen with standard Schlenk techniques, using a double-fold vacuum line. Most of the solvents

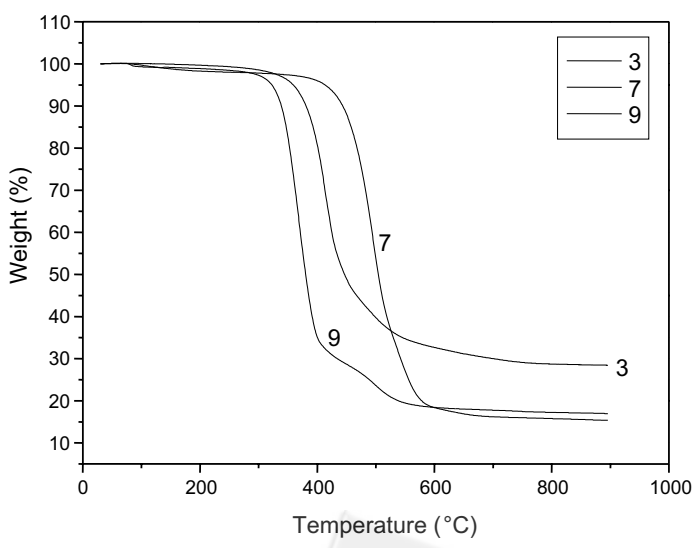

Fig. 1. Thermogravimetric analysis for 3, 7, and $\mathbf{9}$. 
used were distilled from appropriate drying agents. ${ }^{21}$ IR spectra were recorded in $\mathrm{CH}_{2} \mathrm{Cl}_{2}$, using $\mathrm{CaF}_{2}$ optics on a PerkinElmer 882 spectrophotometer. The ${ }^{1} \mathrm{H}$ and ${ }^{13} \mathrm{C}$ NMR spectra were obtained on Bruker AC 200/AC 300 spectrometers. Chemical shifts are reported in $\delta$ values relative to the residual solvent resonance of $\mathrm{CDCl}_{3}\left({ }^{1} \mathrm{H}, \delta 7.24 ;{ }^{13} \mathrm{C}, \delta 77.0\right), \mathrm{C}_{6} \mathrm{D}_{6}$

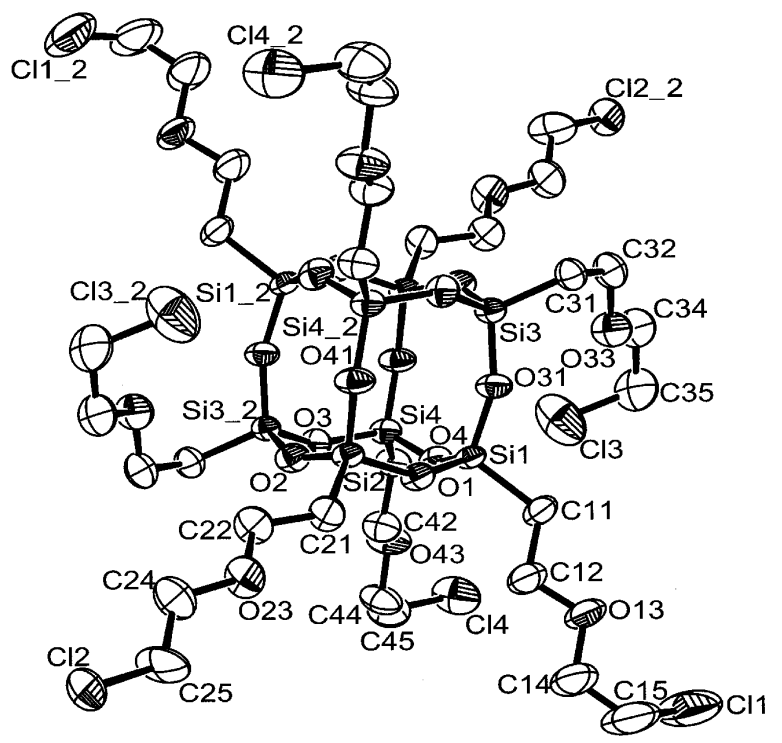

Fig. 2. Molecular structure of 9 with $\mathrm{H}$-atoms, C25', and $\mathrm{Cl2}$ ' omitted for clarity. Selected bond lengths: Si1-O1 1.627(3), Si1-O4 1.616(4), $\mathrm{Si} 1-\mathrm{O} 31$ 1.605(3), Si2-O1 1.614(3), Si2-O2 1.608(4), Si2-O41 1.618(3), Si3-O2 1.613(3), Si3-O3 1.631(3), Si3-O31 1.605(3), Si4-O3 1.621(3), Si4-O4 1.619(4), Si4-O41 1.614(3) Á; Si1-C11 1.842(5), Si2-C21 1.846(5), Si3C31 1.841(5), Si4-C41 1.837(5) A; bond angles: O1-Si1-O4 108.42(19), O1-Si1-O31 108.79(18), O1-Si1-C11 109.01(20), O4-Si1O31 109.52(18), O4-Si1-C11 111.64(23), O31Si1-C11 109.42(23), O1-Si2-O2 109.50(18), O1-Si2-O41 108.45(18), O1-Si2-C21 107.96(20), O2-Si2-O41 108.83(18), O2-Si2-C21 109.98(23), O41-Si2-C21 112.09(24), O2-Si3-O3 108.32(18), O2-Si3-O31 109.44(19), O2-Si3-C31 110.53(21), O3-Si3-O31 107.69(18), O3-Si3-C31 108.74(21), O31-Si3-C31 112.01(21), O3-Si4-O4 108.45(18), O3-Si4-O41 109.97(18), O3-Si4-C41 109.67(22), O4-Si4-O41 110.14(20), O4-Si4-C41 111.28(22), O41-Si4-C41 107.33(21) ${ }^{\circ}$; consecutive torsion angles: Si1-C11-C12-O13-C14-C15-C11 -175.6 ${ }^{\circ}$, $-177.2^{\circ},-179.1^{\circ},-49.8^{\circ}$; Si2-C21-C22-O23$\mathrm{C} 24-\mathrm{C} 25-\mathrm{Cl} 2176.7^{\circ},-174.1^{\circ}, 159.0^{\circ}, 155.0^{\circ}$; $\mathrm{Si3-C} 31-\mathrm{C} 32-\mathrm{O} 33-\mathrm{C} 34-\mathrm{C} 35-\mathrm{Cl} 3-52.4^{\circ}, 169.6^{\circ}$, $178.5^{\circ}, 62.8^{\circ}$; Si4-C41-C42-O43-C44-C45-Cl4 $178.9^{\circ}, 177.3^{\circ},-179.7^{\circ}, 63.8^{\circ}$. $\left({ }^{1} \mathrm{H}, \delta 7.15\right)$, and d-acetone $\left({ }^{1} \mathrm{H}, \delta 2.04\right)$. High resolution FAB-mass spectra were collected on a JEOL JMS-700 double focusing mass spectrometer with a resolution of $8000(5 \%$ valley definition). For FAB-mass spectra, the source accelerating voltage was operated $10 \mathrm{kV}$ with a Xe gun, using 3nitrobenzyl alcohol as matrix. Micro-analytical data were obtained with the use of a Perkin-Elmer 240C elemental analyzer, independently operated by the Institute of Chemistry, Academia Sinica. Thermal gravimetric analyses were performed on a Perkin-Elmer TGA-7 thermogravimetric analyzer where measurements were performed at a rate of 10 ${ }^{\circ} \mathrm{C} / \mathrm{min}$ under air/nitrogen. The melting points were determined on a Fargo melting point apparatus and the values were uncorrected. Reagents/chemicals were obtained from commercial sources, e.g. Aldrich and Fluka, and used without further purification. Acid Amberlite (IR-120) was regenerated after use by washing with concentrated aqueous $\mathrm{HCl}$, water, and methanol.

\section{Synthesis of $\mathrm{H}_{8}-\mathrm{T}_{8}, 1$}

\section{(a) With Agaskar procedure}

$\mathrm{FeCl}_{3}$ (anhydrous, $50 \mathrm{~g}$ ) was taken in a round-bottomed flask, and concentrated aqueous $\mathrm{HCl}(20 \mathrm{~mL})$ was added followed by $\mathrm{CH}_{3} \mathrm{OH}(40 \mathrm{~mL})$. Hexane $(350 \mathrm{~mL})$ was added, and the mixture was stirred. A solution of $\mathrm{HSiCl}_{3}(20 \mathrm{~mL}, 0.2$ $\mathrm{mol})$ in hexane $(150 \mathrm{~mL})$ was added dropwise over a period of $9 \mathrm{~h}$. After an additional $30 \mathrm{~min}$ of stirring, the upper hexane layer was transferred to another round-bottomed flask along with a suspended yellow solid. $\mathrm{K}_{2} \mathrm{CO}_{3}(14 \mathrm{~g})$ and $\mathrm{CaCl}_{2}(10 \mathrm{~g})$ were added to the flask and the contents stirred overnight. The mixture was filtered, and the filtrate volume was reduced by evaporation until it was about $20 \mathrm{~mL} .{ }^{1} \mathrm{H}$ NMR $\left(\mathrm{C}_{6} \mathrm{D}_{6}\right)$ showed that these crystals were a mixture of $\mathrm{H}_{8}-\mathrm{T}_{8}$ and $\mathrm{H}_{10}-\mathrm{T}_{10}$ with singlets at $\delta 4.19$ and 4.23 , respectively. $\mathrm{H}_{10}-\mathrm{T}_{10}$ was eliminated by further washings of the mixture with hexane to give a yield of 1 as $17.5 \%$. 1: ${ }^{1} \mathrm{H}$ NMR $\left(\mathrm{C}_{6} \mathrm{D}_{6}\right): \delta 4.19$ (s, 8H). MS (FAB): $425.4\left(\mathrm{M}^{+}\right)$.

\section{(b) With attempted Amberlite procedure}

A mixture of $\mathrm{CH}_{3} \mathrm{OH}(30 \mathrm{~mL})$ and hexane $(150 \mathrm{~mL})$ were put in a $500 \mathrm{~mL}$ round-bottomed flask containing acid Amberlite (IR 120, 50 g). While stirring, a 10-fold hexane diluted $\mathrm{HSiCl}_{3}(4.0 \mathrm{~mL}, 0.040 \mathrm{~mol})$ was added from a dropping funnel over a period of $6 \mathrm{~h}$ and then stirred overnight. The hexane layer was removed and put into a mixture of $\mathrm{K}_{2} \mathrm{CO}_{3}$ (14 g) and $\mathrm{CaCl}_{2}(10 \mathrm{~g})$ and vigorously stirred for $5 \mathrm{~h}$. The filtrate was evaporated until it was less than $7 \mathrm{~mL}$ in volume. White microcrystals of $\mathbf{1}$ were exclusively collected in 5.1\% 
yield.

Hydrosilylation reaction of $\mathrm{H}_{8}$ - $\mathrm{T}_{8}$ with 4-bromo-1-butene $\mathrm{H}_{8}-\mathrm{T}_{8}\left(0.25 \mathrm{~g}, 5.7 \times 10^{-4} \mathrm{~mol}\right)$ and 4-bromo-1-butene $\left(2.0 \mathrm{~mL}, 1.9 \times 10^{-2} \mathrm{~mol}\right)$ were put in a $5.0 \mathrm{~mL}$ flask. Five drops of $0.1 \mathrm{M} \mathrm{H}_{2} \mathrm{PtCl}_{6}$ in $i$-PrOH were added, and the mixture heated at reflux for $10 \mathrm{~h}$. Excess reactant was removed under vacuum to give a brown viscous liquid $\left\{\mathrm{Br}\left(\mathrm{CH}_{2}\right)_{4}\right\}_{8}-\mathrm{T}_{8} 2$. Yield $=88 \%$. 2: ${ }^{1} \mathrm{H}$ NMR $\left(\mathrm{CDCl}_{3}\right): \delta 0.62\left(\mathrm{~b}, \mathrm{SiCH}_{2}, 2 \mathrm{H}\right)$; 1.53 (b, $\left.\mathrm{CH}_{2}, 2 \mathrm{H}\right) ; 1.83$ (b, $\left.\mathrm{CH}_{2}, 2 \mathrm{H}\right) ; 3.38$ (b, $\left.\mathrm{CH}_{2} \mathrm{Br}, 2 \mathrm{H}\right)$. ${ }^{13} \mathrm{C} \mathrm{NMR}\left(\mathrm{CDCl}_{3}\right): \delta 10.90\left(\mathrm{CH}_{2}\right) ; 21.35\left(\mathrm{CH}_{2}\right) ; 33.52\left(\mathrm{CH}_{2}\right)$. MS (FAB): $1504.04\left(\mathrm{M}^{+}\right.$, parent ion).

\section{Hydrosilylation reaction of $\mathrm{H}_{8}-\mathrm{T}_{8}$ with 5-bromo-1- pentene}

$\mathrm{H}_{8}-\mathrm{T}_{8}\left(0.25 \mathrm{~g}, 5.7 \times 10^{-4} \mathrm{~mol}\right), \mathrm{Pt} / \mathrm{C}(5 \mathrm{mg})$ [or alternatively 8 drops of $0.1 \mathrm{M} \mathrm{H}_{2} \mathrm{PtCl}_{6}$ in $i$-PrOH], and 5-bromo-1pentene $\left(1.5 \mathrm{~mL}, 1.3 \times 10^{-2} \mathrm{~mol}\right)$ were heated at reflux for $17 \mathrm{~h}$ [in the case of $\mathrm{H}_{2} \mathrm{PtCl}_{6}, 7 \mathrm{~h}$ ]. A small amount of ether was then added and filtered over celite. The solution was vacuumdried to afford a white solid $\left\{\mathrm{Br}\left(\mathrm{CH}_{2}\right)_{5}\right\}_{8}-\mathrm{T}_{8}$ 3. Yield $=98 \%$ [in the case of $\mathrm{H}_{2} \mathrm{PtCl}_{6}, 100 \%$ ]. 3: M.p. $67.9{ }^{\circ} \mathrm{C} .{ }^{1} \mathrm{H} \mathrm{NMR}$ $\left(\mathrm{CDCl}_{3}\right): \delta$ 0.59-0.64 (t, $\left.\mathrm{SiCH}_{2}, 2 \mathrm{H}\right) ; 1.42-1.45\left(\mathrm{~m}, \mathrm{CH}_{2}, 4 \mathrm{H}\right)$; 1.80-1.84 (m, $\left.\mathrm{CH}_{2}, 2 \mathrm{H}\right)$; 3.36-3.40 (t, $\left.\mathrm{CH}_{2} \mathrm{Br}, 2 \mathrm{H}\right) .{ }^{13} \mathrm{C}$ NMR $\left(\mathrm{CDCl}_{3}\right)$ : $\delta 11.75\left(\mathrm{SiCH}_{2}\right) ; 22.04\left(\mathrm{CH}_{2}\right) ; 30.99\left(\mathrm{CH}_{2}\right) ; 32.40$ $\left(\mathrm{CH}_{2}\right) ; 33.78\left(\mathrm{CH}_{2} \mathrm{Br}\right)$. IR $\left(\mathrm{CH}_{2} \mathrm{Cl}_{2}\right)$ : 3688.7, 1447.4, 1118.9 $\mathrm{cm}^{-1}$. MS (FAB): $1617.3\left(\mathrm{M}^{+}\right.$, parent ion). Elem. Anal. Calcd. for $\mathrm{C}_{40} \mathrm{H}_{80} \mathrm{O}_{12} \mathrm{Si}_{8} \mathrm{Br}_{8}$ : C $29.73 \%$, H 4.96\%; Found: C 29.79\%, $\mathrm{H} 5.0 \%$.

\section{Hydrosilylation reaction of $\mathrm{H}_{8}$ - $\mathrm{T}_{8}$ with 6-chloro-1-hexene} $\mathrm{H}_{8}-\mathrm{T}_{8}\left(0.25 \mathrm{~g}, 5.7 \times 10^{-4} \mathrm{~mol}\right)$ and 6-chloro-1-hexene $\left(1.20 \mathrm{~mL}, 9.0 \times 10^{-3} \mathrm{~mol}\right)$ were put in a $5.0 \mathrm{~mL}$ flask. Eight drops of $0.1 \mathrm{M} \mathrm{H}_{2} \mathrm{PtCl}_{6}$ in $i$-PrOH were added and the mixture heated at reflux for $10 \mathrm{~h}$. Excess reactant was removed under vacuum to give a clear colorless viscous liquid $\left\{\mathrm{Cl}\left(\mathrm{CH}_{2}\right)_{6}\right\}_{8-}$ $\mathrm{T}_{8}$ 4. Yield $=98 \% .4:{ }^{1} \mathrm{H}$ NMR $\left(\mathrm{CDCl}_{3}\right): \delta$ 0.56-0.61 (t, $\left.\mathrm{SiCH}_{2}, 2 \mathrm{H}\right)$; 1.31-1.39 (m, $\left.\mathrm{CH}_{2}, 6 \mathrm{H}\right)$; 1.68-1.76 (m, $\left.\mathrm{CH}_{2}, 2 \mathrm{H}\right)$; 3.48-3.52 (t, $\left.\mathrm{CH}_{2} \mathrm{Cl}, 2 \mathrm{H}\right) .{ }^{13} \mathrm{C} \mathrm{NMR}\left(\mathrm{CDCl}_{3}\right): \delta 11.80\left(\mathrm{SiCH}_{2}\right)$; $22.60\left(\mathrm{CH}_{2}\right) ; 26.50\left(\mathrm{CH}_{2}\right) ; 31.79\left(\mathrm{CH}_{2}\right) ; 32.48\left(\mathrm{CH}_{2}\right) ; 45.08$ $\left(\mathrm{CH}_{2} \mathrm{Cl}\right)$. IR $\left(\mathrm{CH}_{2} \mathrm{Cl}_{2}\right): 3688.7,1447.4,1117.2 \mathrm{~cm}^{-1}$. MS (FAB): $1373.2\left(\mathrm{M}^{+}\right.$, parent ion). Elem. Anal. Calcd. for $\mathrm{C}_{48} \mathrm{H}_{96} \mathrm{O}_{12} \mathrm{Si}_{8} \mathrm{Cl}_{8}$ : C 41.89, H 6.9; Found: C 41.72, H 6.82.

\section{Hydrosilylation reaction of $\mathrm{H}_{8}-\mathrm{T}_{8}$ with 7-bromo-1- heptene}

$\mathrm{H}_{8}-\mathrm{T}_{8}\left(0.125 \mathrm{~g}, 2.89 \times 10^{-4} \mathrm{~mol}\right)$ in toluene $(3.0 \mathrm{~mL})$ and 7-bromo-1-heptene $\left(1.0 \mathrm{~mL}, 6.5 \times 10^{-3} \mathrm{~mol}\right)$ were put in a 5.0 $\mathrm{mL}$ flask. Eight drops of $0.1 \mathrm{M} \mathrm{H}_{2} \mathrm{PtCl}_{6} i$-PrOH were added and the mixture heated at reflux for $16 \mathrm{~h}$. Toluene and excess reactant were removed under vacuum to give a clear colorless viscous liquid $\left\{\mathrm{Br}\left(\mathrm{CH}_{2}\right)_{7}\right\}_{8}-\mathrm{T}_{8}$ 5. Yield $=90 \%$. 5: ${ }^{1} \mathrm{H} \mathrm{NMR}$ $\left(\mathrm{CDCl}_{3}\right): \delta 0.58$ (b, $\left.\mathrm{SiCH}_{2}, 2 \mathrm{H}\right) ; 1.30-1.37\left(\mathrm{~m}, \mathrm{CH}_{2}, 8 \mathrm{H}\right) ; 1.78$ (b, $\left.\mathrm{CH}_{2}, 2 \mathrm{H}\right) ; 3.36\left(\mathrm{~b}, \mathrm{CH}_{2} \mathrm{Br}, 2 \mathrm{H}\right) .{ }^{13} \mathrm{C} \mathrm{NMR}\left(\mathrm{CDCl}_{3}\right): \delta$ $11.87\left(\mathrm{CH}_{2}\right) ; 22.64\left(\mathrm{CH}_{2}\right) ; 28.03\left(\mathrm{CH}_{2}\right) ; 28.40\left(\mathrm{CH}_{2}\right) ; 32.38$ $\left(\mathrm{CH}_{2}\right) ; 32.78\left(\mathrm{CH}_{2}\right) ; 33.97\left(\mathrm{CH}_{2}\right)$. IR $\left(\mathrm{CH}_{2} \mathrm{Cl}_{2}\right)$ : 3685.2, 1449.0, $1118.3 \mathrm{~cm}^{-1}$. MS (FAB): $1841.41\left(\mathrm{M}^{+}\right.$, parent ion). Elem. Anal. Calcd. for $\mathrm{C}_{56} \mathrm{H}_{112} \mathrm{O}_{12} \mathrm{Si}_{8} \mathrm{Br}_{8}$ : C 36.43\%, H 6.13\%; Found C $35.45 \%$, H $5.84 \%$.

\section{Hydrosilylation reaction of $\mathrm{H}_{8}-\mathrm{T}_{8}$ with 8-bromo-1-octene} 8 -Bromo-1-octene $\left(1.5 \mathrm{~mL}, 8.9 \times 10^{-3} \mathrm{~mol}\right)$ was added to a $5.0 \mathrm{~mL}$ flask containing $\mathrm{H}_{8}-\mathrm{T}_{8}\left(0.25 \mathrm{~g}, 5.7 \times 10^{-4} \mathrm{~mol}\right)$. Eight drops of $0.1 \mathrm{M} \mathrm{H}_{2} \mathrm{PtCl}_{6}$ in $i$-PrOH were added and the mixture heated at reflux for $10 \mathrm{~h}$ before vacuum-removal of excess reactant to give a light brown viscous liquid $\left\{\mathrm{Br}\left(\mathrm{CH}_{2}\right)_{8}\right\}_{8}-\mathrm{T}_{8} \mathbf{6}$. Yield $=96 \%$. 6: ${ }^{1} \mathrm{H} \mathrm{NMR}\left(\mathrm{CHCl}_{3}\right): \delta 0.55\left(\mathrm{~b}, \mathrm{SiCH}_{2}, 2 \mathrm{H}\right) ; 1.27$ (b, $\left.\mathrm{CH}_{2}, 10 \mathrm{H}\right) ; 1.78$ (b, $\left.\mathrm{CH}_{2}, 2 \mathrm{H}\right) ; 3.35$ (b, $\left.\mathrm{CH}_{2} \mathrm{Br}, 2 \mathrm{H}\right) .{ }^{13} \mathrm{C}$ NMR $\left(\mathrm{CDCl}_{3}\right): \delta 11.80,22.60,28.10,28.58,29.00,32.40$, 32.73 \& 33.83 (all $\left.\mathrm{CH}_{2}\right)$. MS (FAB): $1952.2\left(\mathrm{M}^{+}\right.$, parent ion). Elem. Anal. Calcd. for $\mathrm{C}_{64} \mathrm{H}_{128} \mathrm{O}_{12} \mathrm{Si}_{8} \mathrm{Br}_{8}$ : C $39.37 \%$, H 6.56\%; Found C $39.26 \%$, H $6.49 \%$.

\section{Hydrosilylation reaction of $\mathbf{H}_{8}$ - $\mathbf{T}_{8}$ with vinylcyclohexane} To a solution of $\mathrm{H}_{8}-\mathrm{T}_{8}\left(0.25 \mathrm{~g}, 5.7 \times 10^{-4} \mathrm{~mol}\right)$ in hexane $(10.0 \mathrm{~mL})$ in a $25 \mathrm{~mL}$ flask was added vinylcyclohexane $\left(1.80 \mathrm{~mL}, 1.3 \times 10^{-2} \mathrm{~mol}\right)$. Ten drops of $0.1 \mathrm{M} \mathrm{H}_{2} \mathrm{PtCl}_{6}$ in $i$-PrOH were added and the mixture heated at reflux for $3 \mathrm{~d}$. The solvent and excess vinylcyclohexane were removed under vacuum to give a white solid $\left\{\mathrm{C}_{6} \mathrm{H}_{11}\left(\mathrm{CH}_{2}\right)_{2}\right\}_{8}-\mathrm{T}_{8} 7$, which was purified by washing with $\mathrm{CH}_{3} \mathrm{OH}$. Yield $=74 \%$. 7: ${ }^{1} \mathrm{H}$ $\mathrm{NMR}\left(\mathrm{CDCl}_{3}\right)$ : $\delta 0.54$ (b, $\left.\mathrm{SiCH}_{2}, 2 \mathrm{H}\right) ; 0.79\left(\mathrm{~b}, \mathrm{CH}_{2}, 2 \mathrm{H}\right) ; 1.13$ (b, $\left.\mathrm{C}_{6} \mathrm{H}_{11}, 6 \mathrm{H}\right) ; 1.61\left(\mathrm{~b}, \mathrm{C}_{6} \mathrm{H}_{11}, 5 \mathrm{H}\right) .{ }^{13} \mathrm{C} \mathrm{NMR}\left(\mathrm{CDCl}_{3}\right): \delta 9.08$ $\left(\mathrm{SiCH}_{2}\right) ; 30.20\left(\mathrm{CH}_{2} \mathrm{C}_{6} \mathrm{H}_{11}\right) ; 26.39,26.80,32.94,39.94$ (all $\left.\mathrm{C}_{6} \mathrm{H}_{11}\right)$. MS (FAB): $1306.7\left(\mathrm{M}^{+}\right.$, parent ion). Elem. Anal. Calcd. for $\mathrm{C}_{64} \mathrm{H}_{120} \mathrm{O}_{12} \mathrm{Si}_{8}$ : C $58.96 \%$, H 9.27\%, Found $\mathrm{C}$ $59.52 \%$, H 9.60 .

Hydrosilylation reaction of $\mathrm{H}_{\mathbf{8}}$ - $\mathrm{T}_{\mathbf{8}}$ with 6-chloro-1-hexyne To a solution of $\mathrm{H}_{8}-\mathrm{T}_{8}\left(0.25 \mathrm{~g}, 5.7 \times 10^{-4} \mathrm{~mol}\right)$ in toluene $(4.0 \mathrm{~mL})$ in a $10 \mathrm{~mL}$ flask was added 6-chloro-1-hexyne $(1.40$ $\mathrm{mL}, 1.20 \times 10^{-2} \mathrm{~mol}$ ). Six drops of $0.1 \mathrm{M} \mathrm{H}_{2} \mathrm{PtCl}_{6}$ in $i$-PrOH were added and the mixture heated at reflux for $8 \mathrm{~h}$ to give brown viscous liquid $\left\{\mathrm{Cl}\left(\mathrm{CH}_{2}\right)_{4} \mathrm{CH}=\mathrm{CH}\right\}_{\mathrm{n}^{-}}\left\{\mathrm{Cl}\left(\mathrm{CH}_{2}\right)_{4} \mathrm{C}=\mathrm{CH}_{2}\right\}_{(8-\mathrm{n})^{-}}$ 
$\mathrm{T}_{8} \mathbf{8 a}, \mathbf{b}$ (isomeric $\alpha$ and $\beta$ hydrosilylated products which were not further isolated). 8a,b: ${ }^{1} \mathrm{H}$ NMR $\left(\mathrm{CDCl}_{3}\right): \delta 1.53$ (b, $\left.\mathrm{SiCH}_{2}, 2 \mathrm{H}\right) ; 1.69$ (b, $\left.\mathrm{CH}_{2}, 2 \mathrm{H}\right) ; 2.17$ (b, $\left.\mathrm{CH}_{2}, 2 \mathrm{H}\right) ; 3.46$ (b, $\left.\mathrm{CH}_{2}, 4 \mathrm{H}\right) ; 5.41$ (d, $\left.\mathrm{CH}, 1 \mathrm{H}\right) ; 6.36(\mathrm{~d}, \mathrm{CH}, 1 \mathrm{H}) ; 5.68$ (b, $\mathrm{CH}_{2}$, 2H). MS (FAB): 1357.1 ( $\mathrm{M}^{+}$, parent ions for isomers).

\section{Hydrosilylation reaction of $\mathrm{H}_{8}$ - $\mathrm{T}_{8}$ with 2-chloroethyl- vinylether}

2-Chloroethylvinylether $\left(2.0 \mathrm{~mL}, 1.9 \times 10^{-2} \mathrm{~mol}\right)$ was added to a $5.0 \mathrm{~mL}$ flask containing $\mathrm{H}_{8}-\mathrm{T}_{8}\left(0.25 \mathrm{~g}, 5.7 \times 10^{-4}\right.$ mol). Eight drops of $0.1 \mathrm{M} \mathrm{H}_{2} \mathrm{PtCl}_{6}$ in $i$-PrOH were added and the mixture heated at reflux overnight before vacuumremoval of excess reactant to give off-white microcrystals which were washed with hexane $\left\{\mathrm{Cl}\left(\mathrm{CH}_{2}\right)_{2} \mathrm{O}\left(\mathrm{CH}_{2}\right)_{2}\right\}_{8}-\mathrm{T}_{8} 9$. Yield $=98 \%$. 9: ${ }^{1} \mathrm{H}$ NMR $\left(\mathrm{CHCl}_{3}\right): \delta 1.06\left(\mathrm{t}, \mathrm{SiCH}_{2}, 2 \mathrm{H}\right)$; 3.55-3.67 (m, $\left.\mathrm{CH}_{2} \mathrm{OCH}_{2} \mathrm{CH}_{2} \mathrm{Cl}, 6 \mathrm{H}\right) .{ }^{13} \mathrm{C} \mathrm{NMR}\left(\mathrm{CDCl}_{3}\right): \delta$ 13.99, 42.94, 66.65, \& $70.38\left(\right.$ all $\left.\mathrm{CH}_{2}\right)$. MS (FAB): 1275.1 $\left(\mathrm{M}^{+}\right.$, parent ion). Elem. Anal. Calcd. for $\mathrm{C}_{32} \mathrm{H}_{64} \mathrm{O}_{20} \mathrm{Si}_{8} \mathrm{Cl}_{8}$ : C $30.01 \%$, H $4.98 \%$; Found C 29.75\%, H 4.91\%.

\section{X-ray structure analysis of 9}

Diffraction intensities were measured with background counts made for half the total scan time on each side of the peak. Three standard reflections, measured every $60 \mathrm{~min}$, showed no significant decrease in intensity during data collection. Data were corrected for Lorentz-polarization and absorption (empirical $\psi$ corrections). The structure was solved by direct methods MULTAN. ${ }^{22}$ Calculations and full matrix least-squares refinements were performed utilizing the NRCVAX program package. ${ }^{23}$ Disorders were found in that 2 extra atomic positions were also included in the final molecular structure: $\mathrm{C} 12$ with occupancy 0.75 and $\mathrm{C} 12,0.25, \mathrm{C} 25$ with occupancy 0.50 and $\mathrm{C} 25^{\prime}$ ' with 0.50 . All non-H atoms were refined with anisotropic thermal parameters with hydrogen atoms fixed $(\mathrm{C}-\mathrm{H}=1.00 \AA)$. Scattering factor curves of $\mathrm{Cl}, \mathrm{Si}, \mathrm{O}, \mathrm{C}$, and $\mathrm{H}$ were taken from the International Tables. ${ }^{24}$ Crystal data of 9: $\mathrm{C}_{32} \mathrm{H}_{64} \mathrm{Cl}_{8} \mathrm{O}_{20} \mathrm{Si}_{8}$, FW 1277.16; Triclinic P -1, a 8.9592(13), b 12.4123(19), c 13.1479(12) $\AA, \alpha 99.719$ (11), $\beta$ 95.264(11), $\gamma$ 84.052(12) $; \mathrm{V}=1429.2(3) \AA^{3} ; \mathrm{Z}=1$; $\mathrm{F}(000) 664 ; \mathrm{D}_{\text {calc }} 1.477 \mathrm{~g} / \mathrm{cm}^{3} ; \lambda 0.7107 \AA ; \mu 0.63 \mathrm{~mm}^{-1} ; 2 \theta$ $\max 50.0^{\circ}$; Nonius CAD4 data; $-10<\mathrm{h}<10,0<\mathrm{k}<14 ;-15<$ $1<15$; crystal size $0.21 \times 0.24 \times 0.40 \mathrm{~mm}$; transmission factors $0.483-0.868 ; \mathrm{T}=298 \mathrm{~K}$; No. of refined atoms 36 ; No. of calculated atoms 32 ; No. of refined parameters 325 ; No. of unique reflections 5038; No. of observed reflections 3618 [I $>2.0 \sigma(\mathrm{I})] ; \mathrm{R}=0.076 ; \mathrm{R}_{\mathrm{w}}=0.106$; Goodness of fit $=1.76$; $(\Delta / \sigma)_{\max }=0.0001 ;(\mathrm{D}-\operatorname{map})_{\max }=1.050 \mathrm{e} / \AA^{3} ;$ Minimizing function $=\Sigma\left(\mathrm{w}\left\|\mathrm{F}_{\mathrm{o}}|-| \mathrm{F}_{\mathrm{c}}\right\|^{2}\right)$; Weighting scheme = counting sta-
Table 2. Final Fractional Coordinates of Non-hydrogen Atoms of 9

\begin{tabular}{lllll}
\hline Atom & \multicolumn{1}{c}{$\mathrm{x}$} & \multicolumn{1}{c}{$\mathrm{y}$} & \multicolumn{1}{c}{$\mathrm{z}$} & \multicolumn{1}{c}{ Biso } \\
\hline Si1 & $0.62559(15)$ & $0.55395(10)$ & $0.83948(9)$ & $2.75(5)$ \\
$\mathrm{Si} 2$ & $0.54165(15)$ & $0.32253(9)$ & $0.85134(8)$ & $2.69(5)$ \\
Si3 & $0.76642(14)$ & $0.57978(10)$ & $1.07048(9)$ & $2.65(5)$ \\
Si4 & $0.31717(15)$ & $0.65225(10)$ & $0.91708(9)$ & $2.94(6)$ \\
C11 & $0.8684(5)$ & $0.6944(3)$ & $0.3933(2)$ & $15.18(28)$ \\
C12 & $0.3547(3)$ & $-0.2486(2)$ & $0.5220(2)$ & $5.88(10)^{\mathrm{a}}$ \\
C12' & $0.4982(35)$ & $-0.2238(21)$ & $0.5585(16)$ & $23.21(55)^{\mathrm{b}}$ \\
$\mathrm{C} 13$ & $0.5945(3)$ & $0.8754(2)$ & $0.9093(2)$ & $9.43(14)$ \\
$\mathrm{C} 14$ & $-0.0278(3)$ & $1.0540(2)$ & $0.6430(2)$ & $7.91(12)$ \\
O1 & $0.6027(4)$ & $0.4237(2)$ & $0.8097(2)$ & $3.3(1)$ \\
O2 & $0.3644(4)$ & $0.3476(3)$ & $0.8654(2)$ & $3.4(1)$ \\
O3 & $0.2236(4)$ & $0.5452(2)$ & $0.9043(2)$ & $3.4(1)$ \\
O4 & $0.4618(4)$ & $0.6213(3)$ & $0.8490(3)$ & $3.7(2)$ \\
O13 & $0.7809(6)$ & $0.5792(4)$ & $0.5633(3)$ & $6.2(2)$ \\
O23 & $0.5092(5)$ & $0.0252(3)$ & $0.6659(3)$ & $5.3(2)$ \\
O31 & $0.7224(4)$ & $0.5747(3)$ & $0.9488(2)$ & $3.5(1)$ \\
O33 & $0.8732(5)$ & $0.7939(3)$ & $1.0333(3)$ & $5.0(2)$ \\
O41 & $0.6289(4)$ & $0.3105(3)$ & $0.9627(2)$ & $3.8(1)$ \\
O43 & $0.0332(5)$ & $0.8462(3)$ & $0.7482(3)$ & $5.1(2)$ \\
C11 & $0.7280(7)$ & $0.5949(4)$ & $0.7390(4)$ & $4.1(2)$ \\
C12 & $0.6865(9)$ & $0.5476(6)$ & $0.6314(4)$ & $6.4(4)$ \\
C14 & $0.7394(13)$ & $0.5396(8)$ & $0.4599(5)$ & $9.2(5)$ \\
C15 & $0.8292(14)$ & $0.5664(8)$ & $0.3883(5)$ & $9.8(6)$ \\
C21 & $0.5759(7)$ & $0.1981(4)$ & $0.7546(4)$ & $4.3(2)$ \\
C22 & $0.4720(7)$ & $0.1114(4)$ & $0.7477(4)$ & $4.5(2)$ \\
C24 & $0.4097(9)$ & $-0.0567(6)$ & $0.6452(6)$ & $6.6(4)$ \\
C25 & $0.4088(36)$ & $-0.1219(18)$ & $0.5472(18)$ & $8.0(15)^{\mathrm{c}}$ \\
C25' & $0.4817(19)$ & $-0.1436(17)$ & $0.5698(17)$ & $4.7(8)^{\mathrm{d}}$ \\
C31 & $0.9494(6)$ & $0.6353(4)$ & $1.1099(4)$ & $3.6(2)$ \\
C32 & $0.9440(7)$ & $0.7597(5)$ & $1.1236(4)$ & $4.5(3)$ \\
C34 & $0.8382(8)$ & $0.9090(5)$ & $1.0440(5)$ & $5.5(3)$ \\
C35 & $0.7683(10)$ & $0.9363(5)$ & $0.9444(6)$ & $6.6(4)$ \\
C41 & $0.1949(6)$ & $0.7672(4)$ & $0.8748(4)$ & $3.8(2)$ \\
C42 & $0.1258(7)$ & $0.7495(4)$ & $0.7657(4)$ & $4.4(2)$ \\
C44 & $-0.0294(8)$ & $0.8350(5)$ & $0.6441(5)$ & $5.7(3)$ \\
C45 & $-0.1230(8)$ & $0.9358(6)$ & $0.6285(5)$ & $6.3(3)$ \\
\hline
\end{tabular}

${ }^{\mathrm{a}} \mathrm{C} 12$ : occupancy factor $=0.75 .{ }^{\mathrm{b}} \mathrm{C} 12$ ': occupancy factor $=0.25$. ${ }^{\mathrm{c}} \mathrm{C} 25$ : occupancy factor $=0.50 .{ }^{\mathrm{d}} \mathrm{C} 25$ ': occupancy factor $=0.50$.

tistics plus a weight modifier 0.05 . Final fractional coordinates of non-H atoms are given in Table 2, selected structural parameters in the caption of Fig. 2.

\section{ACKNOWLEDGMENT}

The authors are indebted to the Institute of Chemistry, Academia Sinica and the National Research Council, Taiwan, ROC, for financial support. Thanks are due to Mr. Yuh-Sheng Wen for X-ray structure analysis and to Ms. 
Ping-You Lin for high resolution FAB mass measurements.

Received May 28, 2003.

\section{REFERENCES}

1. (a) Shea, D. A. Chem. Rev. 1995, 95, 1431. (b) http://itri.loyola.edu/nano/final/

2. Mark, J. E. CHEMTECH 1989, 19, 230.

3. (a) Voronkov, M. G.; Lavrent'yev, V. I. Top. Curr. Chem. 1982, 102, 199-236. (b) Calzaferri, G. In Tailor-made Silicon-Oxygen Compounds; Corriu, R., Jutzi, P., Eds.; Vieweg: Braunschweig, 1996; Chapter 12. (c) Harrison, P. G. J. Organomet. Chem. 1997, 542, 141. (d) Ribot, F.; Sanchez, C. Comments Inorg. Chem. 1999, 20, 327. (e) Zhang, C. X.; Laine, R. M. J. Am. Chem. Soc. 2000, 122, 6979.

4. Baney, R. H.; Itoh, M.; Sakakibara, A.; Suzuki, T. Chem. Rev. 1985, 95, 1409

5. Agaskar, P. A. U.S. Patent US 5106604 (A), 1992.

6. (a) Hong, B.; Thomas, T. P. S.; Murfee, H. J.; Lebrun, M. J. Inorg. Chem. 1997, 36, 6146. (b) Ropartz, L.; Morris, R. E.; Schwarz, G. P.; Foster, D. F.; Cole-Hamilton, D. J. Inorg. Chem. Commun. 2000, 3, 714. (c) Manson, B. W.; Morrison, J. J.; Coupar, P. I.; Jaffres, P.-A.; Morris, R. E. J. Chem. Soc., Dalton trans. 2001, 1123.

7. Mueller, R.; Koehne, F.; Sliwinski, S. J. Prakt. Chem. 1959, 9,71 .

8. (a) Agaskar, P. A.; Day, V. W.; Klemperer, W. G. J. Am. Chem. Soc. 1987, 109, 5554. (b) Agaskar, P. A. Inorg. Chem. 1990, 29, 1603.

9. Agaskar, P. A. Inorg. Chem. 1991, 30, 2707.

10. For instance, yields were doubled when acid Amberlite (IR120) instead of $\mathrm{HCl}(\mathrm{aq}) / \mathrm{FeCl}_{3}$ (aq) was used in the hydrolytic condensation of $\left(\mathrm{CH}_{2}=\mathrm{CH}_{2}\right) \mathrm{SiCl}_{3}$ to produce $\left(\mathrm{CH}_{2}=\mathrm{CH}_{2}\right)_{8}-\mathrm{T}_{8}$.

11. (a) Dittmar, U.; Hendan, B. J.; Floerke, U.; Marsmann, H. C. J. Organomet. Chem. 1995, 489, 185. (b) Luecke, S.; Stoppek-Langner, K.; Krebs, B.; Laege, M. Z. Anorg. Allg. Chem. 1997, 623, 1243.

12. Bonhomme, C.; Tolédano, P.; Maquet, J.; Livage, J.; Bonhomme-Coury, L. J. Chem. Soc., Dalton Trans. 1997, 1617.

13. (a) Brown, J. F., Jr.; Vogt, L. H., Jr.; Prescott, P. I. J. Am. Chem. Soc. 1964, 86, 1120. (b) Tamaki, R.; Tanaka, Y.; Asuncion, M. Z.; Choi, J.; Laine, R. M. J. Am. Chem. Soc. 2001, 123, 12416.

14. (a) Herren, D.; Buergy, H.; Calzaferri, G. Helv. Chim. Acta
1991, 74, 24. (b) Calzaferri, G.; Herren, D.; Imhof, R. Helv. Chim. Acta 1991, 74, 1278. (c) Calzaferri, G.; Imhof, R. J. Chem. Soc., Dalton Trans. 1992, 3391. (d) Hendan, B. J.; Marsmann, H. C. J. Organomet. Chem. 1994, 483, 33.

15. (a) Rappoport, Z.; Apeloig, Y. The Chemistry of Organic Silicon Compounds; Wiley: New York, 1998, Vol. 2. (b) Said, M. A.; Roesky, H. W.; Rennekamp, C.; Andruh, M.; Schmidt, H.-G.; Noltemeyer, M. Angew. Chem. Int. Ed. Engl. 1999, 38, 661.

16. Chalk, A. J.; Harrod, J. F. J. Am. Chem. Soc. 1965, 89, 16.

17. Speier, J. L. Adv. Organomet. Chem. 1979, 17, 409.

18. Bassindale, A. R.; Gentle, T. E. J. Mater. Chem. 1993, 3, 1319.

19. (a) Mantz, R. A.; Jones, P. F.; Chaffee, K. P.; Lichtenhan, J. D.; Gilman, J. W.; Ismail, I. M. K.; Burgemeister, M. J. Chem. Mater. 1996, 8, 1250. (b) Bolln, C.; Tsuchida, A.; Frey, H.; Muelhaupt, R. Chem. Mater. 1997, 9, 1475.

20. (a) Said, M. A.; Roesky, H. W.; Rennekamp, C.; Andruh, M.; Schmidt, H.-G.; Noltemeyer, M. Angew. Chem. Int. Ed. Engl. 1999, 38, 661. (b) Tacke, R.; Lopez-Mras, A.; Sheldrick, W. S.; Sebald, A. Z. Anorg. Allg. Chem. 1993, 619, 347. (c) Koellner, G.; Muller, U. Acta Crystallogr. 1989, C45, 1106. (d) Shklover, V. E.; Struchkov, Yu. T.; Makarova, N. N.; Andrianov, K. A. Zh. Strukt. Khim.(Russ.) 1978, 19, 1107. (e) Hossain, M. A.; Hursthouse, M. B.; Malik, K. M. A. Acta Crystallogr. 1979, B35, 2258. (f) Nowotny, M.; Maschmeyer, T.; Johnson, B. F. G.; Lahuerta, P.; Thomas, J. M.; Davies, J. E. Angew. Chem. Int. Ed. Engl. 2001, 40, 955. (g) Lucke, S.; Stoppek-Langner, K.; Krebs, B.; Lage, M. Z. Anorg. Allg. Chem. 1997, 623, 1243. (h) Feher, F. J.; Budzichowski, T. A. J. Organomet. Chem. 1989, 373, 153. (i) Dittmar, U.; Hendan, B. J.; Florke, U.; Marsmann, H. C. J. Organomet. Chem. 1995, 489, 185.

21. Perrin, D. D.; Armarego, W. L. F.; Perrin, D. R. Purification of Laboratory Chemicals; Pergamon Press: Oxford, U. K., 1981.

22. Main, P. In Crystallographic Computing 3: Data Collection, Structure Determination, Proteins and Databases; Sheldrick, G. M., Krueger, C., Goddard, R., Eds.; Clarendon: Oxford, U. K., 1985; pp 206-215.

23. Gabe, E. J.; Le Page, Y.; Lee, F. L. In Crystallographic Computing 3: Data Collection, Structure Determination, Proteins and Databases; Sheldrick, G. M., Krueger, C., Goddard, R., Eds.; Clarendon: Oxford, U. K., 1985; pp 167174.

24. Ibers, J. A.; Hamilton, W. C.; Eds. International Tables for X-ray Crystallography; Kynoch: Birmingham, U. K. (current distributor D. Reidel, Dordrecht, The Netherlands), 1974; Vol. 4, Tables 2.2A and 2.3.1D. 